\title{
Botanical composition and seasonal trends of cattle diets in central Argentina
}

\author{
ROBERT M. BÓO, LILIA I. LINDSTRÖM, OMAR R. ELIA, AND MIRTA D. MAYOR
}

\begin{abstract}
Authors are professor and researcher, Departamento de Agronomia (UNS) and Comisión de Investigaciones Científicas de la Provincia de Buenos Aires; assistant, Departamento de Agronomía (UNS); research technician, Consejo Nacional de Investigaciones Cientificas y Técnicas; assistant, Departamento de Agronomia (UNS); Departamento de Agronomia, Universidad Nacional del Sur, 8000 Bahia Blanca. Argentina.
\end{abstract}

\begin{abstract}
Ahstract
About $40,000 \mathrm{~km}^{2}$ of the Caldenal in central semiarid Argentina are rangelands where the most important economic activity is cow-calf operations. Some information on forage species, mainly regarding taxonomy, ecophysiology, and nutritive value, is available, but detailed studies on composition of free-ranging cattle diets are lacking. The objective of this work was to study the botanical composition and seasonal trends of cattle diets in the southern Caldenal. Diets were studied through microscopic analysis of cattle feces collected monthly in a typical plant community during a 12-month period. Grasses were the bulk of the diets, except in November when more than $50 \%$ of the diet was Medicago minima (L.) Grufberg. Highest consumption among the grasses was of Piptochaetium napostaense (Speg.) Hack., one of the dominants in the grass layer. High consumption of Pappophorum mucronulatum Nees, one of the few warm-season grasses in the region, was found during the summer. Caldén (Prosopis caldenla Burk.) pods, consumed in late summer and fall, were the only woody fragments found in appreciable amounts. Classification and ordination techniques were used to analyze seasonal trends. In spite of a relatively high homogeneity in the diets, 2 well-defined seasonal trends were detected, one in the fall-winter period and another in the spring. Cattle diet diversity was minimum during the coldest months of the year.
\end{abstract}

Key Words: Caldenal, free-ranging cattle, classification, ordination

The Southern Espinal (Fernández et al. 1989) or District of the Caldén (Cabrera 1976), commonly called the Caldenal, is a region in central Argentina characterized by the presence of Prosopis caldenia Burk. Vegetation of the Caldenal has been described at a regional scale in La Pampa by Cano et al. (1980); other local studies are those by Boó and Peláez (1991), Cano (1975), and Esterlrich et al. (1985). The most common vegetation type in the southern Caldenal is shrubland with a very rich grass layer. The eastern and more humid portion of the Caldenal has been used as farmland and the driest portion, covering about $40,000 \mathrm{~km}^{2}$ at present, is almost entirely utilized as rangeland in cow-calf operations. Poor range management, with very few exceptions, is the rule and signs of deterioration have been mentioned (Bóo and Peláez 1991, Fernández et al. 1989). Information on forage species is scarce and limited to nutritive quality or ecophysiology of some species assumed to be important components of cattle diets, but studies on cattle diets are lacking. The objective of this work was to analyze the botanical composition and seasonal variation of cattle diets in a typical plant community of the southern Caldenal.

\footnotetext{
Research was funded in part by the Consejo Nacional de Investigaciones Cientificas y Técnicas PID 391560385 . Authors wish to thank Mr. Francisco Russo who provided the land for this research.

Manuscript accepted 8 May 1993.
}

\section{Study Site}

A 600-ha pasture was selected for the study. The site is located in the southeast portion of the province of La Pampa (Argentina) at $38^{\circ} 45^{\prime} \mathrm{S}, 63^{\circ} 45^{\prime} \mathrm{W}$, and $80-\mathrm{m}$ elevation. Average annual rainfall is $448 \mathrm{~mm}$ concentrated in spring and fall, and average annual potential evapotranspiration is $800 \mathrm{~mm}$ (Peláez 1986). Average annual temperature is $15.3^{\circ} \mathrm{C}$ with June the coldest month $\left(7^{\circ} \mathrm{C}\right)$ and January $\left(23.6^{\circ} \mathrm{C}\right)$ the warmest. Soils are classified as Calciustolls with a petrocalcic horizon ("tosca") at an average depth of $0.60 \mathrm{~m}$ (Fcrnández ct al. 1989).

Vegetation at the site has been described by Bóo and Peláez (1991). Woody species cover varies between 50 and $70 \%$ with $P$. flexuosa DC. and $P$. caldenia, the only tree in the area, the most abundant. The herbaceous layer cover varies between 40 and $50 \%$ with Piptochaetium napostaense (Speg). Hack. and Stipa tenuis Phil. as the dominant species; $S$. speciosa Trin. et Rupr. and $S$. gynerioides Phil. are very frequent, and $S$. longiglumis Phil., Poa ligularis Nees and Pappophorum mucronulatum Nees are less abundant. Bare ground is $30-40 \%$ and during wet years is colonized by annuals, mostly Medicago minima (L.) Grufberg and Erodium cicutarium L'Herit. Above-ground net primary production in this plant community for $S$. tenuis was $86.2 \mathrm{~g} / \mathrm{m}^{2}$-year, and 68.4 $\mathrm{g} / \mathrm{m}^{2}$-year for $P$. napostaense as measured for a 12 -month period totalling $532 \mathrm{~mm}$ of rainfall (Distel 1987, Distel and Fernández 1986). These 2 species accounted for $70 \%$ of the total herbaceous cover.

\section{Materials and Methods}

Botanical composition of cattle diets was studied by microscopic analysis of fecal samples (Sparks and Malecheck 1968). A previous study (Lindström, unpublished) provided microhistological information on the species present in the area and training in the technique. Fifteen independent fecal samples from the same number of observed mature cows were collected monthly during 12 successive months. Five microscope slides were prepared from each sample and 40 systematically selected fields per slide were observed using $100 \mathrm{x}$ magnification. This sampling intensity allowed $20 \%(P<0.05)$ precision in the estimation of the mean for individual species with more than a $7 \%$ contribution to the total sample composition (Bóo et al. 1991). In spite of criticisms due to differential digestibility among forage species, fecal analysis is considered an adequate method for studying food habits of free-ranging herbivores (McInnis and Vavra 1987, Migongo-Bake and Hansen 1987).

A data matrix consisting of the percent relative density of identified components of the monthly diets was prepared, which is considered a good estimation of the relative amounts of forage species present in the diets. A secondary matrix of Euclidian dis- 
tances $\left(E D_{j k}\right)$ between all pairs of months was calculated and classified using complete linkage (Sneath and Sokal 1973), an agglomerative hierarchical cluster analysis technique. McInnis et al. (1990) have discussed the potential of this technique in the analysis of seasonal variation of herbivore diets. Distortion of the classification procedure was evaluated through calculation of the cophenetic correlation coefficient $\left(r_{x, y}\right)$ as described by McInnis et al. (1990), and through ordination of the data matrix with DECORANA (Hill 1979). Rainfall was measured at the site with an automatic rain gauge. Daily maximum temperature was measured with a thermometer. Monthly total rainfall and monthly averages of daily temperatures were calculated and used to perform regression analyses on the axes produced by DECORANA. Monthly diversity $\left(\mathrm{N}_{2}\right)$ of cattle diets was calculated as the reciprocal of Simpson's index (Hill 1973), and regressions analyses of monthly rainfall and temperatures on monthly diet diversity were performed.

\section{Results and Discussion}

A total of $602 \mathrm{~mm}$ of rainfall was measured at the site during the 12-month period of the study. Rainfall monthly totals and monthly averages of daily maximum temperatures are shown in Figure 1.

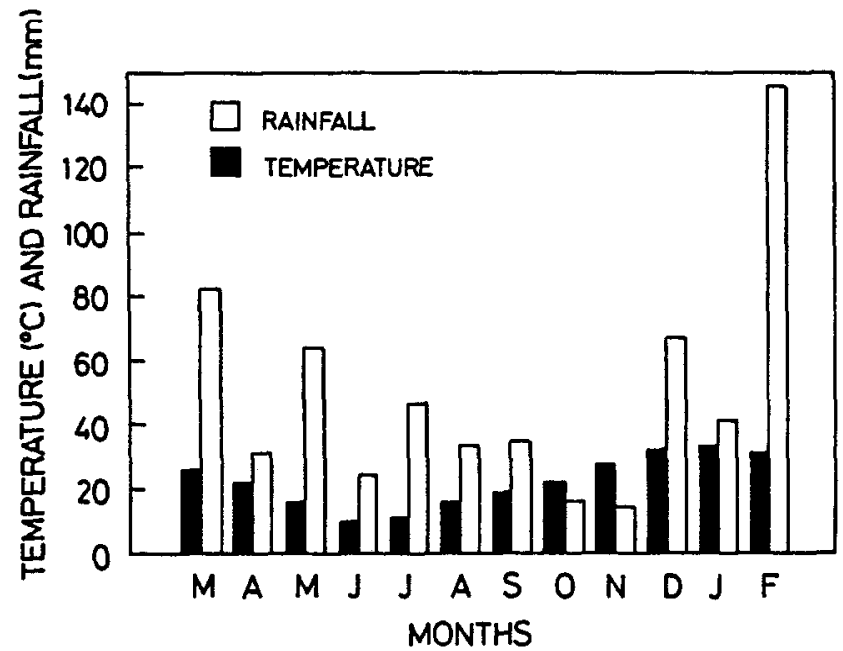

Fig. 1. Totals of monthly rainfall (mm) and monthly averages of daily maximum temperature $\left({ }^{\circ} \mathrm{C}\right)$.

Grasses were the most important contributors to cattle diets throughout the year, with a maximum of $91 \%$ in January, a minimum of $31 \%$ in November and a monthly average of $74 \%$; this finding is coincident with many food habit studies (Holechek et al. 1982, McInnis and Vavra 1987) on free-ranging cattle. $P$. napostaense, one of the dominant grass species in the southern Caldenal, was very abundant in the diets (Fig. 2a) throughout the year, except in mid spring when it was partially replaced by $M$. minima. $S$. tenuis, The other dominant and highly productive cool-season perennial grass in this community (Distel and Fernández 1986) was always present, but with substantial amounts only in late winter and early spring (Fig. 2b). The rest of the grasses showed low abundances, with the exception of $P$. mucronulatum (Fig. 2d), the only warm-season perennial grass present, which reached $48 \%$ in February and showed marked seasonal use.

Two annuals frequently mentioned as a good forage resource and highly productive in this community during the spring (Fresnillo-Fedorenko 1990 ) are $M$. minima and $E$. cicutarium. Only the former (Fig. 2e) made a substantial contribution to the diets. Among the rest of the forbs, only Sphaeralcea spp. St. Hil. (Fig. 2h) are found in low but appreciable amounts, whereas the rest are very scarce or traces.
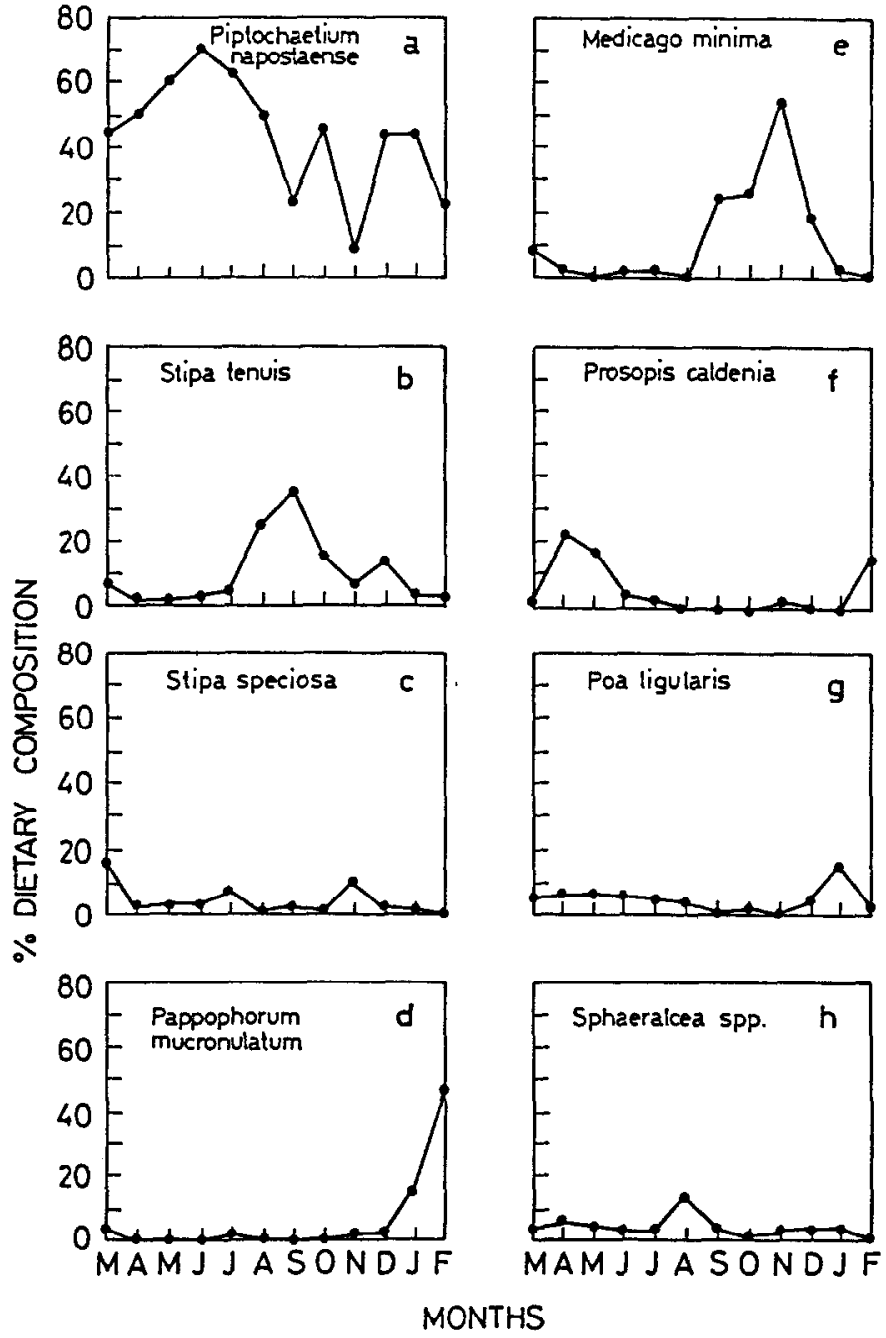

Fig. 2. Monthly variation of species with a contribution of more than $10 \%$ in any one month.

Caldén ( $P$. caldenia) pod fragments were the only abundant woody materials found in the diets. There was a marked seasonal use (Fig. 2f) from mid-summer through late fall, with a peak of $23 \%$ in April. Caldén pods have been mentioned as an important forage resource and experimental work (Menvielle and Hernández 1985) has demonstrated their nutritive quality. However, consumption of caldén pods by free-ranging cattle, in terms of amount and season of use, has never been documented. Consumption of pods is also important because one of the mechanisms responsible for caldén dispersion and shrub encroachment in the Caldenal (Peláez et al. 1992) could be seed scarification through the digestive tract of cattle, and provision of an adequate habitat for seed germination in livestock manure.

Cattle diets have been reported to be more diverse with increased forage availability in late spring (Holechek et al. 1982). Monthly diversity of cattle diets (Fig. 3) decreased from March through June, the coldest month, and then increased until September. Monthly diversity of diets was relatively stable during the rest of the study period, except for November when the minimum diversity for the warmer months was reached; this was coincident with the maximum consumption of $M$. minima. Even though forage biomass was not measured in this study, it can be safely assumed that temperature and water conditions favorable for vegetation growth will increase forage availability. However, a significant correlation was found only between diversity and monthly average 


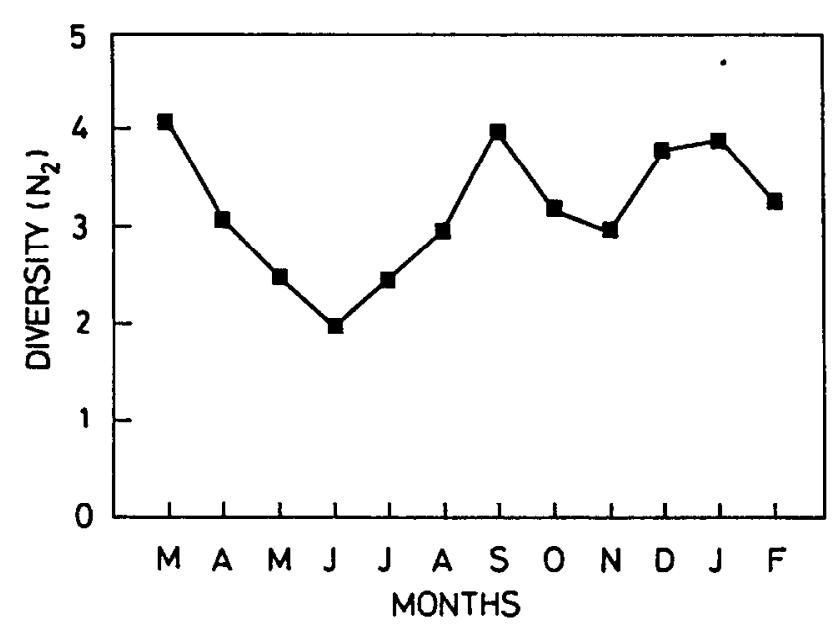

Fig. 3. Monthly diversity of diets calculated as the reciprocal of Simpson's index.

maximum temperature $\left(r_{x, y}=0.73, P<0.01\right)$ and not between diversity and rainfall. This suggests that diet diversity depends on phenological development as well as on forage availability, but the design of this study does not permit us to be more conclusive.

As McInnis et al. (1990) pointed out, there are no defined criteria to stop divisions in the cluster analysis procedure. Since the objective of this study was to analyze seasonal trends, the classification should relate to season. By cutting the tree in the range $31<E D_{i k}<53$ (Fig. 4) 3 clusters are formed (A, B, and C), and February is isolated from the rest behaving as an "outlier"'(sensu Gauch 1982).

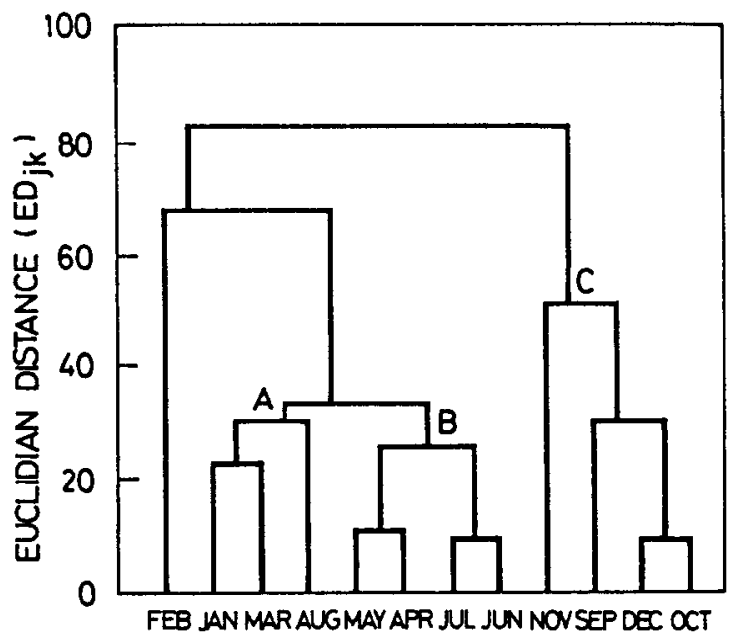

Fig. 4. Dendrogram resulting from classification of monthly diets. A, B, and $C$ indicate defined diet clusters.

In February, almost half of the diet was $P$. mucronulatum making this month very different from the rest.

Cluster $\mathbf{C}$ groups all months from late winter through early summer when the highest consumption of forbs was detected, ranging from $24 \%$ to $61 \%$. Diets in this cluster are characterized by higher abundance of $M$. minima, relatively higher content of $S$. tenuis and lower consumption of $P$. napostaense than in the other clusters. Within cluster differences seem to be due to the relative amounts of these species. Thus, November would be segregated from cluster $\mathrm{C}$ at $\mathrm{ED}_{\mathrm{jk}}<52$ with the highest abundance of $M$. minima and the least of $P$. napostaense for the entire study period.

Cluster B, which includes most of the fall and the first half of winter, has a high within-cluster homogeneity, or close proximity as measured by the $E D_{j k}$ scale. This coincides with the period of minimum diet diversity (Fig. 3). This cluster shows a well-defined seasonal grouping, including the months with the highest consumption of $P$. napostaense, and important contributions of caldén pods to the cattle diets.

Cluster A does not represent a single season, except that January and March are summer months. August showed the highest consumption of Sphaeralcea spp. and a relatively high consumption of S. tenuis.

The cophenetic correlation coefficient $\left(r_{x, y}=0.71\right)$ was relatively low, indicating a certain distortion between the resemblance matrix and the classification procedure, but it does not provide any indication of the nature of such distortion. The use of classification and ordination on the same set of data is recommended (Gauch 1982) as they are considered complementary. Ordination may be useful in the interpretation of clusters and the orthogonal axes are adequate to explore relationships between the data and environmental variables.

Regression analysis of temperature and rainfall on the axes from DECORANA yielded a significant relationship between the first axis and rainfall $\left(\mathrm{r}_{x, y}=0.64, P<0.05\right)$, and between the second axis and monthly average maximum temperature $\left(r_{x, y}=0.58, P<0.05\right)$. These results suggest that rainfall has a greater influence on the seasonal trends of cattle diets than does temperature.

Results from DECORANA are summarized in Figure 5 prepared with the first 2 axes of the ordination, with corresponding eigenvalues of 0.38 and 0.08 . Clusters produced by the classification are also shown in the figure. There is a close grouping of

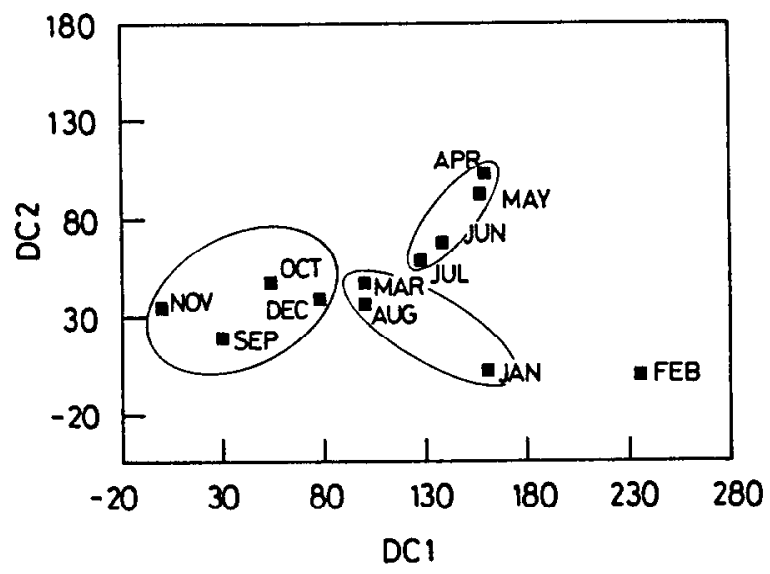

Fig. 5. Distribution of monthly diets in the space defined by the first 2 axes from DECORANA (DC1, DC2). Circled months indicate clusters defined in the classification procedure.

months in cluster B (see Fig. 4) confirming results from the classification. Cluster $\mathbf{C}$, less homogeneous than cluster B, is also evident in the figure. Cluster A, which groups January, March, and August, is heterogeneous as compared to clusters B and C. Of course, this heterogeneity is relative to the total heterogeneity in the data which is indeed very low as the range of the first axis from DECORANA, explaining most of the variation in the data set, covers only 240 units. Two samples separated by 400 units in the axes would have no species in common. Cluster A covers a range of 61 units on the first axis denoting an intrinsically high homogeneity. Perhaps a relatively low cophenetic correlation indicating some distortion could be due to the proximity of March and August to samples in clusters $B$ and $C$. In addition, considering scores on the first axis, there is not a clean separation between clusters A and B mainly due to the position of January. This month, with a relatively high content of $P$. mucronulatum, is the closest to February. The ordination also shows the separation of the February diet from the diets for the rest of the study period. It 
can be concluded that the ordination confirmed the grouping and seasonal trends from the classification and provided a better understanding of relationships among clusters.

\section{Literature Cited}

Bóo, R.M., L.I. Lindström, and E.E. Lutz. 1991. Nủmero de preparados por muestra y número de muestras en la estimación de la composición botánica de heces de vacunos (In Spanish), Rev. Arg. Prod. Anim. 11:13-18.

Bóo, R.M., and D.V. Peláez. 1991. Ordenamiento y clasificación de la vegetación en un área del sur del Caldenal (In Spanish). Bol. Soc. Argent. Bot. 27:135-141.

Cabrera, A.L. 1976. Enciclopedia argentina de agricultura y ganaderia. Regiones fitogeográficas argentinas (In Spanish). Acme, Buenos Aires, Argentina.

Cano, E. 1975. Pastizales en la región central de la provincia de La Pampa (In Spanish). IDIA 331-333:1-15.

Cano, E., B. Fernández, and M.A. Montes. 1980. Región meridional (vegetación) (In Spanish). p. 359-443. In: Prov. de La Pampa, and Univ. Nac. de La Pampa (ed.). Inventario Integrado de Los Recursos Naturales de la Provincia de La Pampa. Buenos Aires, Argentina.

Distel, R.A. 1987. Crecimiento aéreo y radical, germinación y supervivencia en Piptochaetium napostaense (Speg.) Hack y Stipa tenuis Phil (In Spanish). M.S. Thesis, Univ. Nac. del Sur, Bahia Blanca, Argentina.

Distel, R.A., and O.A. Fernández. 1986. Productivity of Stipa tenuis Phil. and Piptochaetium napostaense (Speg.) Hack in semi-arid Argentina. J. Arid Environments 11:93-96.

Esterlrich, H.D., A.D. Collado, and E. Cano. 1985. Relevamiento fitosociológico de un bosque de Prosopis caldenia en la provincia de La Pampa (In Spanish). Rev. Asoc. Pampeana Ciencias Nat. Ser. Sup. 1. p. 36-51.

Fernández, O.A., R.M. Bóo, and L.F. Sánchez. 1989. South American shrublands. In:C.M. McKell (ed). The biology and utilization of shrubs. Academic Press, Inc., USA.
Fresnillo-Fedorenko, D.E. 1990. Estrategias ecológicas de Medicago minima (L.) Grufb. var. minima y Erodium cicutarium (L.) L'Herit., dos anuales de valor forrajero en el Caldenal (In Spanish) M.S. Thesis, Univ. Nac. del Sur, Bahía Blanca, Argentina.

Gauch, H.G. 1982. Multivariate analysis in community ecology. Cambridge Univ. Press, USA.

Hill, M.O. 1973. Diversity and evenness: a unifying notation and its consequences. Ecology 54:427-432.

Hill, M.O. 1989. DECORANA. A fortran program for detrended correspondence analysis and reciprocal averaging. Cornell Univ., Ithaca, N.Y.

Holechek, J.L., M. Vavra, J. Skovlin, and W.C. Krueger. 1982. Cattle diets in the Blue Mountains of Oregon, I. Grasslands. J. Range Manage. 35:109-112.

McInnis, M.L., and M. Vavra. 1987. Dietary relationships among feral horses, cattle, and pronghorn in southeastern Oregon. J. Range Manage. 40:60-66.

McInnis, M.L., L.L. Larson, and M. Vavra. 1990. Classifying herbivore diets using hierarchical cluster analysis. J. Range Manage. 43:271-274.

Menvielle, E.E., and O.A. Hernández. 1985. El valor nutritivo de las vainas de Caldén (In Spanish). Rev. Arg. Prod. Anim. 5:435-439.

Migongo-Bake, W., and R.M. Hansen. 1987. Seasonal diets of camels, cattle, sheep, and goats in a common range in eastern Africa. J. Range Manage. 40:76-79.

Peláez, D.V. 1986. Análisis de algunos factores ambientales y morfológicos y su relación con la aplicación de herbicidas en cinco especies arbutivas del distrito fitogeográfico del Caldén (In Spanish). M.S. Thesis, Univ. Nac. Del Sur, Bahia Blanca, Argentina.

Peláez, D.V., R.M. Bóo, and O.R. Elía. 1992. Emergence and seedling survival of caldén in the semiarid region of Argentina. J. Range Manage. 45:564-568.

Sneath, P.H.A., and R.R. Sokal. 1973. Numerical taxonomy. W.H. Freeman and Co., USA.

Sparks, D.R., and J.C. Malechek. 1968. Estimating percentage dry weight in diets using a microscopic technique. J. Range Manage. 21:264-265. 